\title{
Last nine-thousand years of temperature variability in Northern Europe
}

\author{
H. Seppä ${ }^{1}$, A. E. Bjune ${ }^{2}$, R. J. Telford ${ }^{2}$, H. J. B. Birks ${ }^{3,4}$, and S. Veski ${ }^{5}$ \\ ${ }^{1}$ Department of Geology, P.O. Box 65, 00014, University of Helsinki, Helsinki, Finland \\ ${ }^{2}$ Bjerknes Centre for Climate Research, c/o Department of Biology, University of Bergen, Allégaten 41, 5007 Bergen, Norway \\ ${ }^{3}$ Department of Biology, University of Bergen, Allégaten 41, 5007 Bergen, Norway \\ ${ }^{4}$ Environmental Change Research Centre, University College London, Gower Street, London WC1E 6BT, UK \\ ${ }^{5}$ Institute of Geology, Tallinn University of Technology, Ehitajate tee 5, 19086 Tallinn, Estonia
}

Received: 27 April 2009 - Published in Clim. Past Discuss.: 27 May 2009

Revised: 10 August 2009 - Accepted: 27 August 2009 - Published: 18 September 2009

\begin{abstract}
The threat of future global warming has generated a major interest in quantifying past climate variability on centennial and millennial time-scales. However, palaeoclimatological records are often noisy and arguments about past variability are only possible if they are based on reproducible features in several reliably dated datasets. Here we focus on the last 9000 years, explore the results of 36 Holocene pollen-based July mean and annual mean temperature reconstructions from Northern Europe by stacking them to create summary curves, and compare them with a high-resolution, summary chironomid-based temperature record and other independent palaeoclimate records. The stacked records show that the "Holocene Thermal Maximum" in the region dates to 8000 to 4800 cal yr BP and that the " 8.2 event" and the "Little Ice Age" at 500-100 cal yr BP are the clearest cold episodes during the Holocene. In addition, a more detailed analysis of the last 5000 years pinpoints centennial-scale climate variability with cold anomalies at 3800-3000 and 500$100 \mathrm{cal} \mathrm{yr} \mathrm{BP,} \mathrm{a} \mathrm{long,} \mathrm{warmer} \mathrm{period} \mathrm{around} 2000 \mathrm{cal}$ yr BP, and a marked warming since the mid 19th century. The colder (warmer) anomalies are associated with increased (decreased) humidity over the northern European mainland, consistent with the modern high correlation between cold (warm) and humid (dry) modes of summer weather in the region. A comparison with the key proxy records reflecting the main forcing factors does not support the hypothesis that solar variability is the cause of the late-Holocene centennialscale temperature changes. We suggest that the reconstructed anomalies are typical of Northern Europe and their occurrence may be related to the oceanic and atmospheric circulation variability in the North Atlantic - North-European region.
\end{abstract}

Correspondence to: $\mathrm{H}$. Seppä

(heikki.seppa@helsinki.fi)

\section{Introduction}

The climate of Northern Europe is characterized by high multi-scale variability, related to the changing modes and intensities of the atmospheric and oceanic circulation processes (Philipp et al., 2007; Jones and Lister, 2009). It is here that Andersson (1902, 1909), using predominantly fossil plant evidence, laid the foundations of our modern understanding of the general features of post-glacial climatic trends, including the concept of the early- to mid-Holocene warm period, termed here the Holocene Thermal Maximum (HTM), followed by late-Holocene or neoglacial cooling characterized by historically-documented excursions such as the Medieval Warm Period (MWP) or the Little Ice Age (LIA) (Lamb, 1982). As the climate conditions during the Holocene, including the HTM and the neoglacial cooling, provide a reference for the modelled and predicted future climate changes at high latitudes, it is of great importance to understand better the fundamental nature of Holocene temperature variability and its links to external forcing factors, atmospheric and oceanic processes, and feedback mechanisms (Steig, 1999; Kaufman et al., 2004; Rimbu et al., 2004; Seppä et al., 2005; Jansen et al., 2007; Bakke et al., 2008; Beer and van Geel 2008; Wanner et al., 2008).

In the North-European mainland, especially in the lowlands east of the Scandes Mountains, the biological proxies preserved in lake sediments provide the most available and important source for quantitative palaeoclimatological investigations. The most significant recent technical and conceptual advances in using fossil evidence for climate reconstructions in continental regions include the development of robust and realistic quantitative reconstruction techniques (Birks, 1998, 2003), consistently designed, regionally-restricted calibration sets for the development of more reliable organism-based multivariate transfer functions (Birks, 2003; Seppä et al., 2004), and the comparative use of

Published by Copernicus Publications on behalf of the European Geosciences Union. 
fossil-based reconstructions with independent physical and chemical proxy techniques (Lotter et al., 2000; Seppä et al., 2005). Due to these advances it is possible to produce numerical climate reconstructions than can be used to test palaeoclimatic hypotheses based on climate model simulations, hence offering the possibility of using model-data comparisons for evaluating the relative roles of different climatic forcing factors and feedback responses as drivers of Holocene climatic change (TEMPO, 1996; Prentice et al., 1998; Crucifix et al., 2002; Bonfils et al., 2004; Renssen et al., 2005, 2009). In addition, due to the improved chronological control and increased time resolution of the reconstructions it is becoming possible to identify and evaluate statistically the occurrence of centennial-scale warmer and colder periods and to compare reliably the details of the continental palaeoclimatic records with those from marine and ice-core records and the output of climate simulations focusing on fine-scale Holocene variability (Renssen et al., 2006; Jongma et al., 2007).

During the last decade intense efforts have taken place in Northern Europe to create, expand, and improve organismbased calibration models and to produce new quantitative reconstructions so as to increase the accuracy and spatial coverage of the palaeoclimate records. Here we summarize the results of pollen-based Holocene temperature reconstructions along two transects in Northern Europe, ranging from the Norwegian Atlantic coast to $26^{\circ} \mathrm{E}$ in Estonia and Finland and from $57^{\circ} \mathrm{N}$ in Southern Fennoscandia to $70^{\circ} \mathrm{N}$ in the borealarctic boundary in Northern Fennoscandia. These transects are designed to allow us to investigate regional patterns in climate history related to the pronounced south-north temperature gradient and west-east oceanicity-continentality gradient of Northern Europe (Giesecke et al., 2008). In addition, inclusion of several temporally-detailed and consistentlygenerated palaeoclimatic reconstructions provides an opportunity to test the hypotheses about the broad-scale variability of the Holocene climate. An influential but controversial hypothesis suggests that, in addition to the orbitally-forced secular temperature changes, Holocene climate has been repeatedly punctuated by cold events, occurring at roughly 1500-year intervals (Bond et al., 1997, 2001), and being possibly connected to reductions in solar output (Bond et al., 2001). Evidence for these repeated cold events, however, is not present in many of the high-resolution marine and terrestrial climate reconstructions from the North Atlantic and its eastern seaboard and the generality of these records has therefore been questioned and intensively discussed (Seppä and Birks, 2002; Risebrobakken et al., 2003; Schulz et al., 2004; Turney et al., 2005; Jansen et al., 2007; Wanner et al., 2008). The new well-dated, high-resolution data sets presented here provide therefore an opportunity to assess the potential occurrence of the hypothesized cold episodes in the North-European continental climate history.

\section{Area, material and methods}

\subsection{Pollen-based temperature reconstructions}

We carried out pollen-based quantitative climate reconstructions from 36 pollen stratigraphies obtained from lake sediments (Table 1). All lakes were selected and sampled using consistent criteria (Seppä and Birks, 2001; Seppä et al., 2004). Annual mean temperature $\left(T_{\text {ann }}\right)$ was reconstructed from 12 lakes located in the lowland east of the Scandes Mountians, in Central Fennoscandia and Estonia, between $57^{\circ}-62^{\circ} \mathrm{N}$, in the gradual boundary between the northern temperate zone and southern boreal zone (Fig. 1). July mean temperature $\left(T_{\mathrm{jul}}\right)$ was reconstructed from 23 lakes located between $68^{\circ}-70^{\circ} \mathrm{N}$ in the North-Fennoscandian treeline region and in the ecotonal regions in western and southern Norway (Fig. 1). The altitudinal (alpine) ecotone in southern Norway, the latitudinal (arctic) ecotone in Northern Fennoscandia and the boreal-temperate ecotone in Southern Fennoscandia and the Baltic countries are predominantly temperature-controlled and represent suitable settings for using pollen data for investigating long-term temperature changes.

The calibration model used for reconstructing the $T_{\text {jul }}$ values consists of 321 modern surface-sediment samples of which 283 from Norway, 11 from Svalbard (Norway), and 27 from Northern Sweden (Seppä and Birks, 2001; Birks et al., unpublished). The model used for $T_{\mathrm{ann}}$ reconstructions comprises 113 samples from Finland, 24 samples from Estonia and 36 samples from Sweden (Antonsson et al., 2006). Modern $T_{\text {jul }}$ and $T_{\text {ann }}$ values were estimated using the 1961-1990 Climate Normals data from grids of nearby meteorological stations in Norway, Sweden, Finland, and Estonia. For more detailed information on site selection, fieldwork and modern climate data, see Seppä and Birks (2001) and Seppä et al. (2004).

Modern pollen-climate transfer functions were developed using weighted-averaging partial least squares (WA-PLS) regression (ter Braak and Juggins, 1993). All terrestrial pollen and spore taxa were used in the transfer function. Their percentages were transformed to square-roots in an attempt to optimize the "signal" to "noise" ratio and to stabilize the variances. WA-PLS was selected because it has been shown in many empirical and several theoretical studies to perform as well as or even better than other regression and calibration procedures commonly used to develop organismenvironmental transfer functions (see ter Braak et al., 1993; Birks, 1995, 1998).

The performance of the WA-PLS transfer function models are reported (Table 2) as the root mean square error of prediction (RMSEP), the coefficient of determination $\left(R^{2}\right)$ between observed and predicted values, and the maximum bias (ter Braak and Juggins, 1993), all based on leave-oneout cross-validation or jack-knifing (ter Braak and Juggins, 1993; Birks, 1995). Two-component WA-PLS models were 
Table 1. The 36 sites used for the pollen-based temperature reconstructions. The numbers refer to the numbers in Fig. 1.

\begin{tabular}{|c|c|c|c|c|c|c|c|c|c|c|}
\hline number & name & alt & long & lat & $\begin{array}{r}\text { modern } \\
T_{\mathrm{ann}} \\
\text { or } T_{\mathrm{jul}}\end{array}$ & vegetation zone & country & $\begin{array}{l}\text { number of } \\
\text { samples } 9 \mathrm{ka} \\
\text { to present }\end{array}$ & $\begin{array}{l}\text { number } \\
\text { of }{ }^{14} \mathrm{C} \\
\text { dates }\end{array}$ & reference \\
\hline 1 & Laihalampi & 137 & $61^{\circ} 29^{\prime} \mathrm{N}$ & $26^{\circ} 04^{\prime} \mathrm{E}$ & $3.9 T_{\mathrm{ann}}$ & Southern Boreal & Finland & 122 & 6 & Heikkilä and Seppä (2003) \\
\hline 2 & Nautajärvi & 104 & $61^{\circ} 48^{\prime} \mathrm{N}$ & $24^{\circ} 41^{\prime} \mathrm{E}$ & $4.0 T_{\mathrm{ann}}$ & Southern Boreal & Finland & 240 & varved & Ojala et al. (2008) \\
\hline 3 & Arapisto & 133 & $60^{\circ} 35^{\prime} \mathrm{N}$ & $24^{\circ} 05^{\prime} \mathrm{E}$ & $4.5 T_{\mathrm{ann}}$ & Southern Boreal & Finland & 82 & 7 & Sarmaja-Korjonen and Seppä (2007) \\
\hline 4 & Kuivajärvi & 106 & $60^{\circ} 48^{\prime} \mathrm{N}$ & $23^{\circ} 48^{\prime} \mathrm{E}$ & $4.0 T_{\mathrm{ann}}$ & Southern Boreal & Finland & 97 & 4 & this paper \\
\hline 5 & Rouge & 510 & $57^{\circ} 44^{\prime} \mathrm{N}$ & $26^{\circ} 45^{\prime} \mathrm{E}$ & $5.5 T_{\mathrm{ann}}$ & Boreo-Nemoral & Estonia & 227 & $\begin{array}{l}\text { varved, } \\
\text { PSV-dated }\end{array}$ & this paper \\
\hline 6 & Raigastvere & 53 & $58^{\circ} 35^{\prime} \mathrm{N}$ & $26^{\circ} 39^{\prime} \mathrm{E}$ & $5.0 T_{\mathrm{ann}}$ & Boreo-Nemoral & Estonia & 90 & 10 & Seppä and Poska (2004) \\
\hline 7 & Viitna & 74 & $59^{\circ} 27^{\prime} \mathrm{N}$ & $26^{\circ} 05^{\prime} \mathrm{E}$ & $5.0 T_{\mathrm{ann}}$ & North Boreal & Estonia & 33 & 7 & Seppä and Poska (2004) \\
\hline 8 & Klotjärnen & 235 & $61^{\circ} 49^{\prime} \mathrm{N}$ & $16^{\circ} 32^{\prime} \mathrm{E}$ & $4.5 T_{\mathrm{ann}}$ & Southern Boreal & Sweden & 104 & 6 & this paper \\
\hline 9 & Stora Gilltjärnen & 172 & $60^{\circ} 05^{\prime} \mathrm{N}$ & $15^{\circ} 50^{\prime} \mathrm{E}$ & $4.6 T_{\mathrm{ann}}$ & Southern Boreal & Sweden & 83 & 8 & Antonsson et al. (2006) \\
\hline 10 & Lilla Gloppsjön & 198 & $59^{\circ} 50^{\prime} \mathrm{N}$ & $14^{\circ} 35^{\prime} \mathrm{E}$ & $5.0 T_{\mathrm{ann}}$ & Southern Boreal & Sweden & 73 & 11 & this paper \\
\hline 11 & Flarken & 108 & $58^{\circ} 33^{\prime} \mathrm{N}$ & $13^{\circ} 40^{\prime} \mathrm{E}$ & $5.9 T_{\mathrm{ann}}$ & Boreo-Nemoral & Sweden & 91 & 13 & Seppä et al. (2005) \\
\hline 12 & Trehörningen & 112 & $58^{\circ} 33^{\prime} \mathrm{N}$ & $11^{\circ} 36^{\prime} \mathrm{E}$ & $6.1 T_{\mathrm{ann}}$ & Boreo-Nemoral & Sweden & 49 & 11 & Antonsson and Seppä (2007) \\
\hline 13 & Litlvatnet & 106 & $68^{\circ} 31^{\prime} \mathrm{N}$ & $14^{\circ} 52^{\prime} \mathrm{E}$ & $12 T_{\mathrm{jul}}$ & North Boreal & Norway & 35 & 6 & Birks and Peglar (unpublished) \\
\hline 14 & Myrvatnet & 200 & $68^{\circ} 39^{\prime} \mathrm{N}$ & $16^{\circ} 23^{\prime} \mathrm{E}$ & $12.5 T_{\text {jul }}$ & North Boreal & Norway & 41 & 6 & Birks and Peglar (unpublished) \\
\hline 15 & Austerkjosen & 135 & $68^{\circ} 32^{\prime} \mathrm{N}$ & $17^{\circ} 16^{\prime} \mathrm{E}$ & $12.8 T_{\mathrm{jul}}$ & North Boreal & Norway & 27 & 6 & Birks and Peglar (unpublished) \\
\hline 16 & Gammelheimenvatnet & 290 & $68^{\circ} 28^{\prime} \mathrm{N}$ & $17^{\circ} 45^{\prime} \mathrm{E}$ & $12.8 T_{\mathrm{jul}}$ & Mid/Northern Boreal & Norway & 62 & 8 & Birks and Peglar (unpublished) \\
\hline 17 & Bjørnfjelltjørn & 510 & $68^{\circ} 26^{\prime} \mathrm{N}$ & $18^{\circ} 04^{\prime} \mathrm{E}$ & $10.5 T_{\mathrm{jul}}$ & Low Alpine & Norway & 46 & 8 & Birks and Peglar (unpublished) \\
\hline 18 & Vuoskkujavri & 390 & $68^{\circ} 20^{\prime} \mathrm{N}$ & $19^{\circ} 09^{\prime} \mathrm{E}$ & $11 T_{\mathrm{jul}}$ & North Boreal & Sweden & 49 & 10 & Bigler et al. (2002) \\
\hline 19 & Alanen Laanijärvi & 365 & $67^{\circ} 58^{\prime} \mathrm{N}$ & $20^{\circ} 29^{\prime} \mathrm{E}$ & $12.5 T_{\text {jul }}$ & Norh Boreal & Sweden & 56 & 6 & Heinrichs et al. (2005) \\
\hline 20 & Svanåvatnet & 243 & $66^{\circ} 25^{\prime} \mathrm{N}$ & $14^{\circ} 03^{\prime} \mathrm{E}$ & $12.1 T_{\mathrm{jul}}$ & Middle Boreal & Norway & 61 & 4 & Bjune and Birks (2008) \\
\hline 21 & Dalmutladdo & 355 & $69^{\circ} 10^{\prime} \mathrm{N}$ & $20^{\circ} 43^{\prime} \mathrm{E}$ & $11.5 T_{\mathrm{jul}}$ & North Boreal & Norway & 56 & 11 & Bjune et al. (2004) \\
\hline 22 & Toskaljavri & 526 & $69^{\circ} 12^{\prime} \mathrm{N}$ & $21^{\circ} 28^{\prime} \mathrm{E}$ & $9.7 T_{\text {jul }}$ & Arctic-alpine & Finland & 146 & 8 & Seppä and Birks (2002) \\
\hline 23 & Tsuolbmajavri & 704 & $68^{\circ} 41^{\prime} \mathrm{N}$ & $22^{\circ} 05^{\prime} \mathrm{E}$ & $11 T_{\mathrm{jul}}$ & Arctic-alpine & Finland & 135 & 13 & Seppä and Birks (2001) \\
\hline 24 & Hopseidet & 225 & $70^{\circ} 50^{\prime} \mathrm{N}$ & $27^{\circ} 43^{\prime} \mathrm{E}$ & n.a. $T_{\text {jul }}$ & Arctic-alpine & Norway & 38 & 4 & this paper, Seppä (1998) \\
\hline 25 & $\mathrm{KP}-2$ & 131 & $68^{\circ} 48^{\prime} \mathrm{N}$ & $35^{\circ} 19^{\prime} \mathrm{E}$ & n.a. $T_{\text {jul }}$ & North Boreal & Russia & 62 & 8 & Seppä et al. (2008) \\
\hline 26 & Haugtjern & 338 & $60^{\circ} 50^{\prime} \mathrm{N}$ & $10^{\circ} 53^{\prime} \mathrm{E}$ & $14.4 T_{\mathrm{jul}}$ & Southern Boreal & Norway & 61 & 8 & Birks and Peglar (unpublished) \\
\hline 27 & Kinnshaugen & 591 & $61^{\circ} 61^{\prime} \mathrm{N}$ & $10^{\circ} 22^{\prime} \mathrm{E}$ & $12.9 T_{\mathrm{jul}}$ & Middle Boreal & Norway & 45 & 8 & Birks and Peglar (unpublished) \\
\hline 28 & Svartvatnet & 183 & $63^{\circ} 21^{\prime} \mathrm{N}$ & $8^{\circ} 93^{\prime} \mathrm{E}$ & $12.1 T_{\mathrm{jul}}$ & Southern Boreal & Norway & 44 & 10 & Birks and Peglar (unpublished) \\
\hline 29 & Tiåvatnet & 464 & $63^{\circ} 03^{\prime} \mathrm{N}$ & $9^{\circ} 25^{\prime} \mathrm{E}$ & $11.3 T_{\mathrm{jul}}$ & Middle Boreal & Norway & 72 & 8 & Birks and Peglar (unpublished) \\
\hline 30 & Dalane & 40 & $58^{\circ} 15^{\prime} \mathrm{N}$ & $8^{\circ} 00^{\prime} \mathrm{E}$ & $14.9 T_{\text {jul }}$ & Nemoral & Norway & 47 & 8 & Eide et al. (2006) \\
\hline 31 & Flotatjønn & 890 & $59^{\circ} 40^{\prime} \mathrm{N}$ & $7^{\circ} 33^{\prime} \mathrm{E}$ & $10.4 T_{\mathrm{jul}}$ & North Boreal & Norway & 38 & 5 & Birks and Peglar (unpublished) \\
\hline 32 & Grostjørna & 180 & $58^{\circ} 32^{\prime} \mathrm{N}$ & $7^{\circ} 44^{\prime} \mathrm{E}$ & $15.2 T_{\mathrm{jul}}$ & Southern Boreal & Norway & 52 & 7 & Eide et al. (2006) \\
\hline 33 & Holebudalen & 1144 & $59^{\circ} 50^{\prime} \mathrm{N}$ & $7^{\circ} 00^{\prime} \mathrm{E}$ & $8.2 T_{\text {jul }}$ & Low Alpine & Norway & 61 & 7 & Eide et al. (2006 \\
\hline 34 & Isbenttjønn & 787 & $59^{\circ} 46^{\prime} \mathrm{N}$ & $7^{\circ} 26^{\prime} \mathrm{E}$ & $10.5 T_{\mathrm{jul}}$ & North Boreal & Norway & 52 & 7 & Birks and Peglar (unpublished) \\
\hline 35 & Lille Kjelavatn & 1000 & $59^{\circ} 48^{\prime} \mathrm{N}$ & $7^{\circ} 15^{\prime} \mathrm{E}$ & $9.3 T_{\text {jul }}$ & Sub Alpine & Norway & 72 & 6 & Eide et al. (2006) \\
\hline 36 & Reiarsdalvatnet & 245 & $58^{\circ} 19^{\prime} \mathrm{N}$ & $7^{\circ} 47^{\prime} \mathrm{E}$ & $14.3 T_{\mathrm{jul}}$ & Boreo Nemoral & Norway & 77 & 8 & Birks and Peglar (unpublished) \\
\hline
\end{tabular}

selected (Table 2) on the basis of low RMSEP, low maximum bias, and the smallest number of 'useful' components (Birks, 1998). More details of the modern pollen-climate data-sets are given in Seppä and Birks (2001), Seppä et al. (2004), and Antonsson et al. (2006).

The reason for reconstructing $T_{\text {jul }}$ for the high-latitude sites in Northern Fennoscandia and the high-altitude sites in Western and Southern Norway and $T_{\text {ann }}$ for the lowland sites in Central and Southern Fennoscandia is that in the tree-line sites the growing season is confined to three or four summer months (MJJA) and a vegetation-based proxy such as pollen arguably reflects predominantly summer temperature conditions. This is not the case in the central and southern Fennoscandian lowlands, where the growing season is considerably longer, starting often in March or April and continuing to October (Walther and Linderholm, 2006). In addition, winter climatic conditions are important for the distribution and regeneration of many plant species, especially those restricted to the most oceanic parts along the west coast of Fennoscandia (Dahl, 1998; Giesecke et al., 2008). Thus the pollen records represent a mixture of taxa with different
Table 2. The data and performance statistics, all based on leaveone-out cross-validation, about the two pollen-based calibration models $($ FES = Finland, Estonia, Sweden; NSS = Norway, Svalbard, Sweden).

\begin{tabular}{lll}
\hline & $\begin{array}{l}\text { FES calibration } \\
\text { model for } T_{\text {ann }}\end{array}$ & $\begin{array}{l}\text { NSS calibration } \\
\text { model for } T_{\text {jul }}\end{array}$ \\
\hline number of sites & 173 & 321 \\
temperature gradient & -4.1 to $7.1^{\circ} \mathrm{C}$ & $3.5-16.4^{\circ} \mathrm{C}$ \\
number of taxa & 104 & 183 \\
RMSEP & $0.95^{\circ} \mathrm{C}$ & $1.135^{\circ} \mathrm{C}$ \\
$R^{2}$ & 0.88 & 0.77 \\
maximum bias & $2.1^{\circ} \mathrm{C}$ & $2.53^{\circ} \mathrm{C}$ \\
\hline
\end{tabular}

temperature requirements in relation to the seasons. Annual mean temperature is thus probably a more appropriate climatic parameter to be reconstructed from pollen data in Southern and Central Fennoscandia than July mean temperature (Seppä et al., 2004). 


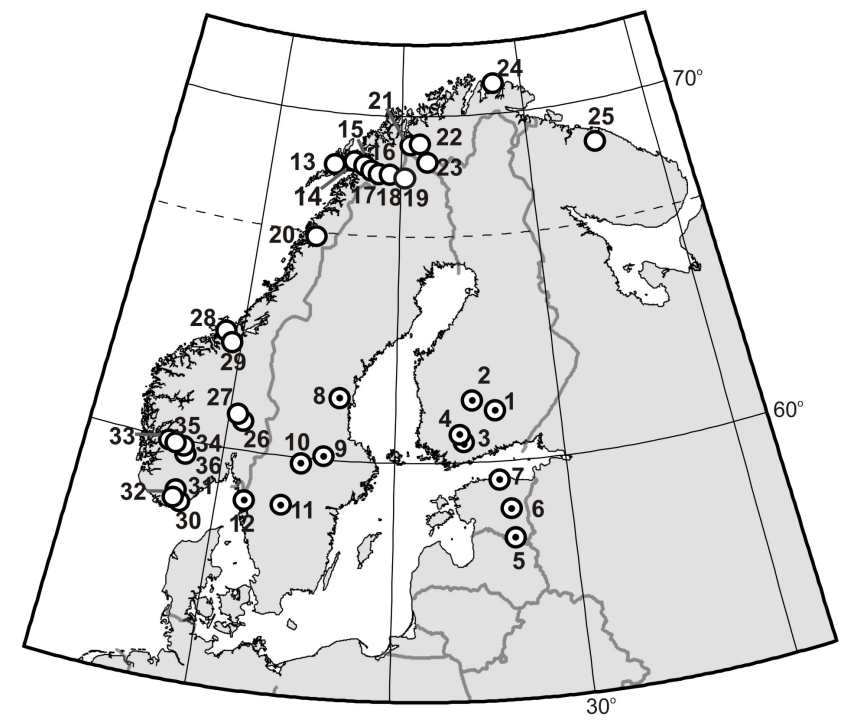

Fig. 1. The location of the sites from where the quantitative pollenbased temperature reconstructions where derived. The filled circles indicate sites with $T_{\text {ann }}$ reconstructions and open circles with $T_{\text {jul }}$ reconstructions. For the name of the sites, see Table 1.

\subsection{Age-depth models}

The chronology for 33 of the 36 lake-sediment cores is based in AMS radiocarbon dating. The number of dates per core ranges from 4 to 13 (Table 1). All ages were calibrated to calendar years using CALIB4.3 (Stuiver and Reimer, 1993) or CALIB5.0 (Stuiver et al., 2005) software and INTCAL98 (Stuiver et al., 1998) or INTCAL04 (Reimer et al., 2004) calibration data. For sites 1, 3, 8-9, 11-23 and 25-36 the age-depth models are based on a mixed effect weighted regression procedure within the framework of generalized additive models (Heegaard, 2003; Heegaard et al., 2005). For sites $4,6,7,10$, and 24 the age-depth model was obtained by fitting a second-order polynomial curve (third-order with lake 24) to the calibrated dates. Lakes 2 and 5 are particularly important in the present context due to their high sample resolution (Table 1). Lake 2 is an annually laminated lake and has therefore an accurate chronology for the last 9000 years (Ojala and Tiljander, 2003). Lake 5 is partly annually laminated but the varve chronology is floating. The chronology and age-depth model for the lake were derived by correlating the palaeomagnetic secular variation (PSV) curve with the clear anchor points of the PSV curve of lake 2. The obtained chronology is supported by AMS dates (Veski et al., 2004)

The sediment cores were collected in 1990s and early 2000s and the uppermost $0-1 \mathrm{~cm}$ of the sediment is believed to represent the present-day.

\section{Results and discussion}

\subsection{General climatic trends}

We first examine the implications of the general temperature trends. Figure 2 portrays the results of the individual $T_{\text {ann }}$ and $T_{\text {jul }}$ reconstructions for the last 9000 years. The trends and their differences can be assessed from the LOESS smoothers fitted to the records. Many sites (for example 1, 3, 5, 6, 8, 10,11 , and 12) show that $T_{\mathrm{ann}}$ was about $2.0-2.5^{\circ} \mathrm{C}$ higher than at present during the earlier part of the HTM at 8000 to 6000 cal yr BP. Importantly, this is the same temperature deviation as calculated originally by Andersson (1902) in Central Sweden and as later reconstructed by the direct borehole temperature measurements of the GRIP ice-core in Greenland (Dahl-Jensen et al., 1998). $T_{\text {jul }}$ values at all sites show a lower temperature deviation during the HTM, the maximum values at $8000-6000 \mathrm{cal}$ yr $\mathrm{BP}$ being about $1.5^{\circ} \mathrm{C}$ higher than at present.

Individual time-series climate records are usually noisy and always include chronological error. To be able to distinguish more reliably the main features we calculated the deviations from the mean for all individual records and stacked them into two records of $T_{\text {ann }}$ and $T_{\text {jul }}$ (Fig. $3 \mathrm{a}$ and $\mathrm{b}$ ) and combined these two records to provide a "stacked summary curve", which shows the general temperature deviations in Northern Europe (Fig. 3c). The stacked $T_{\text {ann }}$ record shows a steadily increasing temperature from $9000 \mathrm{cal} \mathrm{yr} \mathrm{BP}$ onwards, reaching the maximum Holocene level at 8000 cal yr. The subsequent period of highest $T_{\text {ann }}$ values, the HTM, lasted over 3000 years, and corresponds therefore with the classical "post-glacial climatic optimum" (Andersson, 1909). As obvious in the individual records (Fig. 2), the magnitude of the HTM warming in the stacked $T_{\text {jul }}$ record is lower than in the $T_{\text {ann }}$ record. The HTM does not appear as a multimillennial period, but $T_{\mathrm{jul}}$ is highest at $8000-7000 \mathrm{cal} \mathrm{yr}$ and declines then steadily towards the present, thus strongly resembling the summer insolation curve for comparable latitudes (Fig. 3d). The stacked summary curve is understandably a combination of these two curves, with a fairly clear HTM at $8000-4800$ cal yr BP.

\subsection{Early- and mid-Holocene events}

The most conspicuous cold event in our records takes place at about 8300 to $8000 \mathrm{cal}$ yr BP, clearly representing the freshwater-forced North-Atlantic $8.2 \mathrm{ka}$ event (Alley et al., 1997; Alley and Àgústsdóttir, 2005; Wiersma and Renssen, 2006). The cooling is present in many $T_{\text {ann }}$ records (especially sites $3,4,5,8$, and 11), mostly located in the ecotone of the temperate and boreal zones, where thermophilous tree taxa occur near their northern range limit. The high-resolution records from this region show a cooling of about $1.0^{\circ} \mathrm{C}$, followed by abrupt, high-magnitude warming of about $2.0^{\circ} \mathrm{C}$ in less than 50 years (Veski et al., 2004). 

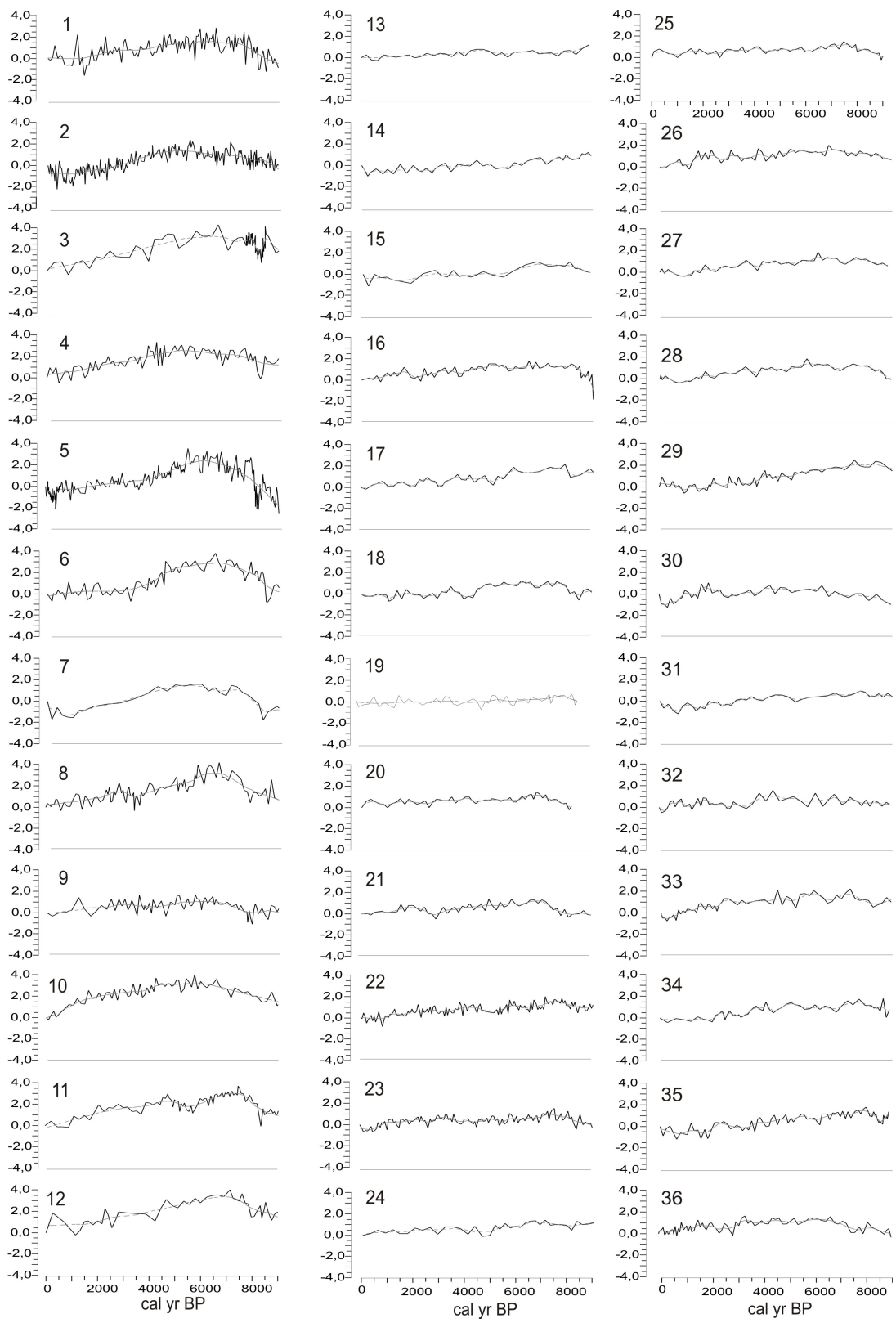

Fig. 2. The individual pollen-based $T_{\mathrm{ann}}$ and $T_{\text {jul }}$ reconstructions for the last 9000 years. Sites numbered as in Table 1 .

No or weak evidence for the cooling can be observed in the $T_{\text {jul }}$ records obtained from Norway, the northern tree-line region, or in the stacked $T_{\text {jul }}$ record (Figs. 2 and 3b). Seppä et al. (2007) discuss this spatial pattern and its possible causes. One factor that may explain the clearer evidence in the south is that both evidence and simulations of the $8.2 \mathrm{ka}$ event suggest that the cooling took place mostly during the winter on the eastern North Atlantic seaboard (Alley and Àgústsdóttir, 2005; Wiersma and Renssen, 2006). In the southern part of our study region the vegetative growth pattern, regeneration and pollen productivity are more sensitive to winter and early spring temperatures than in Northern Fennoscan- dia. However, the relatively weak evidence for the cooling on the Norwegian west coast and Southern Norway (sites 2535 in Fig. 2), where a strong cooling is suggested by models (Wiersma and Renssen, 2006), is not fully consistent with this explanation and thus requires further attention in the future.

The stacked $T_{\text {ann }}$ record shows some variability during the HTM (Fig. 3a), with colder periods at about 7000 and $5300 \mathrm{cal}$ yr BP. These wiggles are not replicated in the $T_{\mathrm{jul}}$ record, suggesting that they may not represent regionally significant climatic events. However, Sommer et al. (2009) showed that the regional extirpation of the European pond 


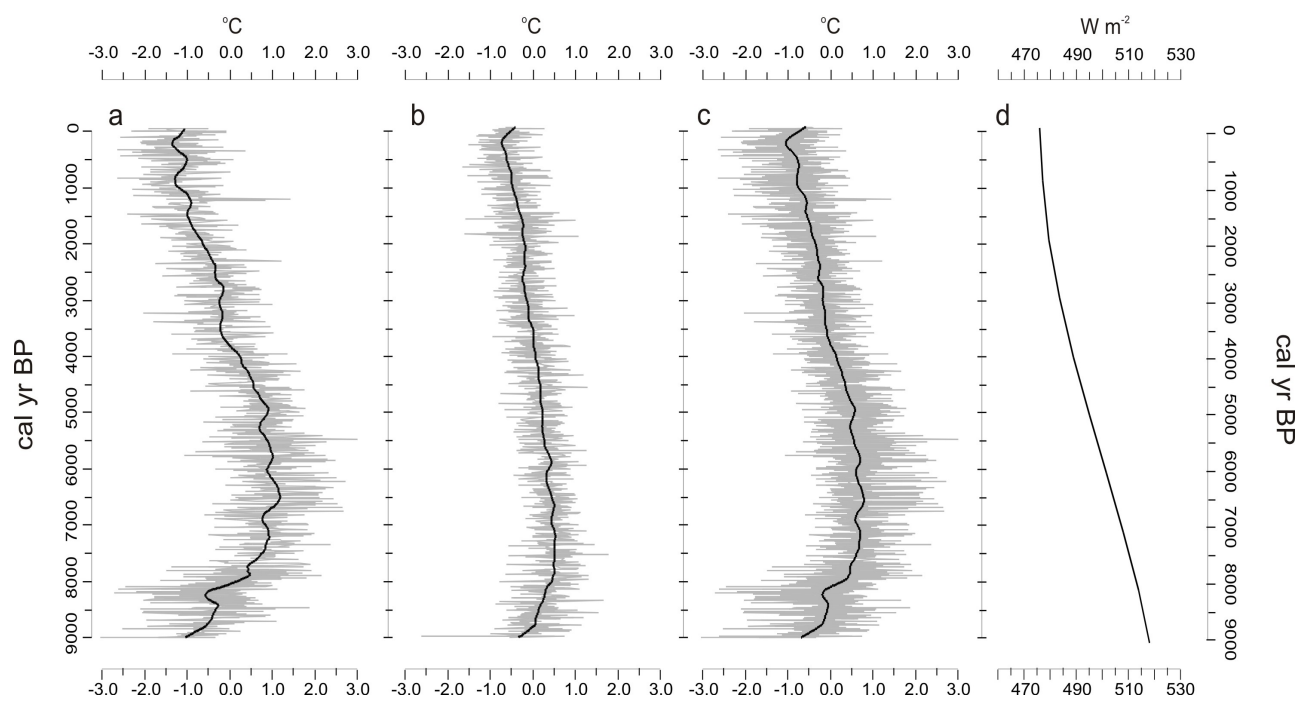

Fig. 3. The North-European pollen-based stacked $T_{\text {ann }}$ (a) and $T_{\text {jul }}$ (b) records. The $T_{\text {ann }}$ record comprises a total of 1291 reconstructed $T_{\text {ann }}$ values (average sample interval of 7.0 years) and the stacked $T_{\text {jul }}$ record based on 1561 values (average sample interval 5.8 years) for the 9000 years. The temperature values are expressed as deviations from the mean. These two records are combined in (c) to show "a stacked summary curve" reflecting the North-European temperature variability record, consisting of 2852 values with an average sample interval of 3.2 years. All records are shown with a LOESS smoother with a span of 0.05 . (d) June insolation at $60^{\circ} \mathrm{N}$ northern latitude (Berger and Loutre, 1991).

turtle, a temperate species intolerant of cold summer, happened in Fennoscandia at about 5500 cal yr BP, probably due to a cold spell. Moreover, evidence for a large regional cooling at 5800-5100 cal yr BP has been reported from the North Atlantic and central Europe (O'Brien et al., 1995; Oppo et al. 2003; Magny and Haas, 2004; Moros et al., 2004; Vollweiler et al., 2006), and the strong signal in the Greenland glaciochemical proxies may be linked to an enchanced Eurasian high (Mayewski et al., 1997), suggesting that the cooling may have been associated with a decreased strength of the westerly circulation in Northern Europe.

\subsection{Late-Holocene variability}

The stacked records in Fig. 3 show that the last 5000 years have been characterized by a roughly linear cooling trend. To investigate the potential warmer and colder anomalies embedded in this long-term cooling trend, we detrended the stacked summary record for the last 5000 years by fitting a linear curve. The residuals after detrending are shown in Fig. 4a. This curve is compared with a stacked chironomidbased July mean temperature record from Fennoscandia (Fig. 4b), that provides an independent high-resolution summer temperature curve. These two records are compared with two $\delta^{18} \mathrm{O}$ curves from lacustrine carbonates (Fig. 4c) and an accurately-dated plant macrofossil-based surface wetness record from Southern Finland (Fig. 4d). The $\delta^{18} \mathrm{O}$ records reflect predominantly temperature changes, but are connected through evapotranspiration to lake-level and humidity changes (Hammarlund et al., 2003; Seppä et al.,
2005), whereas the bog surface wetness records in the Baltic Sea region are probably a more direct proxy for changes in effective precipitation and general humidity (Charman et al., 2004; Väliranta et al., 2007). Estimates of late-Holocene winter precipitation changes exist (e.g. Bakke et al., 2008), but their comparison with pollen- or chironomid-based $T_{\text {jul }}$ or $T_{\text {ann }}$ reconstructions is more ambiguous.

All five records show generally comparable main features. Three periods of positive deviations and thus high temperature in relation to the trend date to 5000$4000 \mathrm{cal} \mathrm{yr} \mathrm{BP,} 3000-1000 \mathrm{cal} \mathrm{yr} \mathrm{BP}$ and to the last about 150 years $(100 \mathrm{cal} \mathrm{yr} \mathrm{BP}$ to about AD 2000). The period at $5000-4000$ cal yr BP dates to the end of the HTM and is characterized by high temperature and low humidity. These are the typical climatological features of the end of the HTM particularly in the more continental part of Fennoscandia, where the levels of many of the hydrologically-sensitive lakes fell several metres or dried out at after 8000 cal yr BP until a rise after $4000 \mathrm{cal} \mathrm{yr} \mathrm{BP} \mathrm{(Hyvärinen} \mathrm{and} \mathrm{Alhonen,}$ 1994; Almquist-Jacobson 1995; Hammarlund et al., 2003; Korhola et al., 2005; Sohar and Kalm, 2008).

The second warm anomaly at $3000-1000$ cal yr BP in the pollen-based record is consistent with the positive deviations in the chironomid-based $T_{\text {jul }}$ record, with the rise of $\delta^{18} \mathrm{O}$ values in the lacustrine carbonate records, and with increasingly dry conditions in the surface wetness reconstruction. This period, which seems to peak at around $2000 \mathrm{cal} \mathrm{yr} \mathrm{BP,}$ has not been widely investigated or documented earlier in Northern Europe. In central Europe this period appears as a ca. 2000-year long period of relatively high temperature 


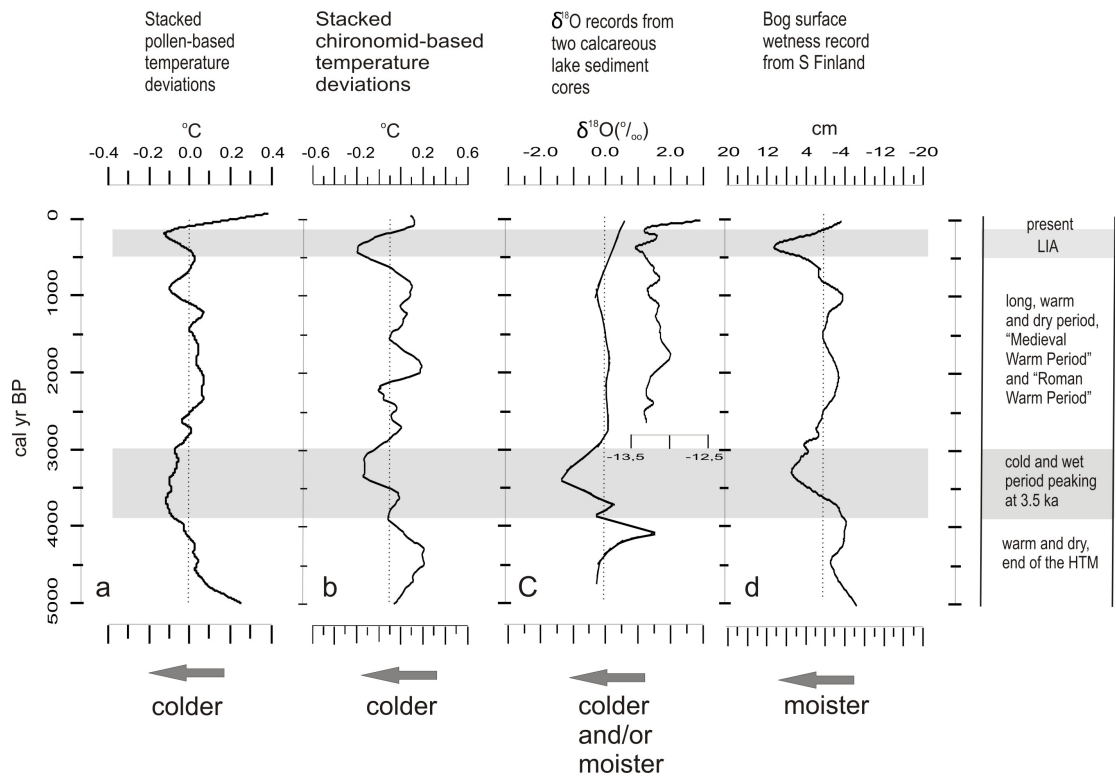

Fig. 4. The temperature variability in Northern Europe during the last 5000 years. (a) the pollen-based temperature variability record based on the stacked summary record. The reconstructed trend during the last 5000 was detrended by adding a linear curve and the residuals are shown here, smoothed with a LOESS smoother with span 0.1. (b) a chironomid-based July mean temperature variability, as reflected by residuals after detrending by adding a linear curve. The chironomid-based curve is a stacked record, based on six sites in Norway (Velle et al., 2005) and one site, Toskaljavri, in Northern Finland (Seppä et al., 2002), showing the deviations from the mean with a LOESS smoother with span 0.1 , (c) Two $\delta^{18} \mathrm{O}$-based records from lacustrine calcareous sediments, from Lake Igelsjön in southern Sweden (Hammarlund et al., 2003) (residuals after detrending), and Lake Tibetanus in Northern Sweden (Rosqvist et al., 2007), reaching back to 2600 cal yr BP, (d) a general humidity record based on bog surface wetness changes reconstructed quantitatively from plant macrofossil composition in southern Finland (Väliranta et al., 2007).

and low humidity. In the Alps, for example, glaciological evidence supported by archaeological finds suggests a marked alpine glacier retreat peaking at $2100-1800 \mathrm{cal}$ yr BP, reflecting thus warm and dry conditions (Jörin et al., 2006; Grosjean et al., 2007) In general, the warm period can be connected with the Roman Warm Period, dating to around 2000 cal yr BP, and with the Medieval Warm Period at about 1000 cal yr BP (Mann, 2007). These two periods are sometimes separated by a shorter colder spell that may have centred on 1500-1400 cal yr BP (Grudd, 2008; Larsen et al., 2008), but this historically documented cold spell ("Dark Age Cold Period") may have been triggered by a volcanic eruption and may be thus too short to be even detected by our stacked data.

It is noteworthy that the MWP cannot be clearly observed in the stacked pollen-based record, nor in the chironomidbased record (Fig. 4). Both records show a generally warm trend with a transition to a colder period starting in the pollen-record already at $1100 \mathrm{cal}$ yr BP and in the chironomid-record at 900 cal yr BP. These features support many earlier investigations according to which the MWP is not reflected as a clear peak in Northern Europe, but rather represents the final centuries of a longer warm period before the onset of cooling at $1000-800 \mathrm{cal}$ yr BP towards the lower temperatures during the LIA (Bradley et al., 2003; Bjune et al., 2009).
The third period with positive temperature deviations dates to last about 150 years. This post-LIA warming has been recorded in many proxy-based reconstructions, for example in the Fennoscandian tree-line region (Weckström et al., 2006; Rosqvist et al., 2007; Bjune et al., 2009). It agrees with historical data about summer and winter temperature trends during the previous five centuries in the region. For example, the longest meteorological records from Sweden show a winter warming since early 1700 s (Bergström and Moberg, 2002) and the historical records of ice break-up dates from the Baltic Sea show a winter and spring warming starting already at 1700 s and intensifying from the mid 1800 s to the present (Tarand and Nordli, 2001). On the basis of their pollen-based reconstructions from 11 sites in the Fennoscandian tree-line region, Bjune et al. (2009) argued that during the 20th century summers were warmest since about $1000 \mathrm{cal}$ yr BP. The same recent warming pattern can be observed in the present, more extensive $T_{\mathrm{jul}}$ reconstruction (Fig. 3b) and in the $T_{\text {ann }}$ reconstruction reflecting only Central and Southern Fennoscandia and the Baltic region (Fig. 3a). The warming that began in the 1800s and reversed the long-term cooling trend has therefore been a large-scale phenomenon in Northern Europe, and probably even in the whole circum-arctic region (Kaufman et al., 2009). 
Two colder anomalies can be identified during the last 5000 years, dating to $3800-3000 \mathrm{cal} \mathrm{yr} \mathrm{BP}$ and to 500 $100 \mathrm{cal}$ yr BP. Many records from Northern Europe give evidence of the onset of a cooling trend at about 45004000 yearcal yr BP, but few previous studies emphatically identify a colder anomaly at $3800-3000 \mathrm{cal}$ yr BP. Some proxy records, for example from Northern Sweden (Rosén et al., 2002) and Finland (Ojala and Tiljander, 2003), suggest a colder period around $3500 \mathrm{cal}$ yr BP and high-resolution sedimentary analyses focusing on the HTM-neoglaciation transition in Southern Sweden pinpoints a cold period at 4000$3500 \mathrm{cal} y r$, with most severe aquatic response peaking at 3800 cal yr BP (Jessen et al., 2005). This colder event also has equivalence in some records in Northern Europe and North Atlantic (Nesje et al., 2001; Charman et al., 2006). The bog surface wetness record (Fig. 4d) shows that the lower temperature was associated with increased humidity at 35003200 cal yr BP (Väliranta et al., 2007). This is consistent with the evidence of Rundgren (2008) who interpreted combined peat-stratigraphical records in Sweden to reflect particularly moist condition, a "wet-shift" peaking at 3300 cal yr.

The last cold anomaly at 500-100 cal yr BP corresponds with the LIA, the most frequently identified cold period in proxy records from Northern Europe. In general, our reconstructed timing and magnitude of the LIA agrees with the results of the more detailed investigations based on dendrochronological data from Northern Fennoscandia (Grudd, 2008) and with the peak of the LIA in Europe, dated from late 1500s to early 1800s (Bradley and Jones, 1993; Moberg et al., 2005). This agreement is noteworthy because it shows that despite the human influence on vegetation composition and land-cover the pollen-based records still capture the main climate trends in the ecotonal areas. This may be partly due to the direct influence of climate on pollen productivity near species distribution limits (Hicks, 1999; Seppä et al., 2007) and partly because most of our sites have been selected from such settings where human influence has been less intense than in the more densely inhabited and cultivated regions. This is particularly true for the sites located in Northern Fennoscandia where the evidence for LIA is clearest (Bjune et al., 2009).

\subsection{Forcing factors}

A remarkable feature in the climate variability during the last 5000 years is the consistency between the proxies reflecting temperature and humidity. During the last 5000 years the warm anomalies have been associated with dry conditions and cold anomalies with humid conditions. This is undoubtedly partly due to the higher evapotranspiration associated with higher temperature, but is probably partly a result of the nature of the key atmospheric circulation processes in the region. At present in Northern Europe, highest summer temperature anomalies are linked to the anticyclonic circulation type, with the blocking anticyclone as its extreme form, char- acterized by a long-lived high pressure system centred over Scandinavia, causing weak westerly flow and leading thus to reduced precipitation (Chen and Hellström, 1999; Busuioc et al., 2001; Antonsson et al., 2008; Carrill et al., 2008). Antonsson et al. (2008) suggested that the markedly long warm and dry mid-Holocene period at $8000-5000$ cal yr BP in Northern Europe was associated with predominantly anticyclonic summer circulation. The present evidence suggests that this connection between high summer temperature, low humidity and, by inference, anticyclonic circulation may explain even the centennial to multi-centennial-scale climate variability during the late-Holocene. The GISP-2 ice-core $\mathrm{Cl}$ ion concentration record is often inferred as an indicator of predominantly marine airmasses over Greenland and therefore a proxy for strong Icelandic low and westerly airflow in the North-Atlantic-Eurasian region (Mayewski et al., 1997) (Fig. 5d). There is some correlation, albeit weak, between the $\mathrm{Cl}$ record and our temperature record, especially during the cold period at 3800-3000 cal yr BP, but this support for the suggested circulation dynamics is tentative at most, especially because the relationship between the ice-core $\mathrm{Cl}$ concentration and atmospheric circulation over Northern Europe is relatively poorly constrained.

The assessment of the forcing factors behind the inferred climatic and circulation changes is more complicated, but some preliminary assessment can be done by comparing the reconstructed patterns with the proxy records reflecting the magnitude changes in the main forcings. The roughly linear cooling trend during the last 5000 years most likely reflects the high-latitude temperature response to the decline of the summer and annual insolation values (Wanner et al., 2008; Renssen et al., 2009). The suggested deviations from this trend, such as the LIA or the cool period at 3800$3000 \mathrm{cal} \mathrm{yr} \mathrm{BP}$, result therefore from the influence of forcing factors other than insolation, with solar irradiation changes and volcanic aerosol, land-cover, and greenhouse gas forcings as the most likely candidates (Wanner et al., 2008). The detrended deviation of the atmospheric ${ }^{14} \mathrm{C} /{ }^{12} \mathrm{C}$ ratio record is generally interpreted as a proxy for solar irradiance variability during the Holocene (Weber et al., 2004; Beer and van Geel, 2008). In general, the correlation between our temperature records and solar irradiance variability is poor (Fig. 5). Neither the cold anomalies nor the warm anomalies appear to be connected with positive or negative anomalies in the detrended $\delta^{14} \mathrm{C}$ data: the LIA maybe an exception to this. The peak of LIA centres in the North-European records to 450100 cal yr BP, consistent with a positive $\delta^{14} \mathrm{C}$ anomaly, and it may have been brought about by the coincidence of low $\mathrm{NH}$ orbital forcing during the late-Holocene, with unusually low solar activity and a high number of major volcanic eruptions (Wanner et al., 2008).

A test of the statistically significant features, including potential cyclicity, in our summary curves is currently underway. This task in non-trivial, however, given that the test must account for the statistical errors of the reconstructed 


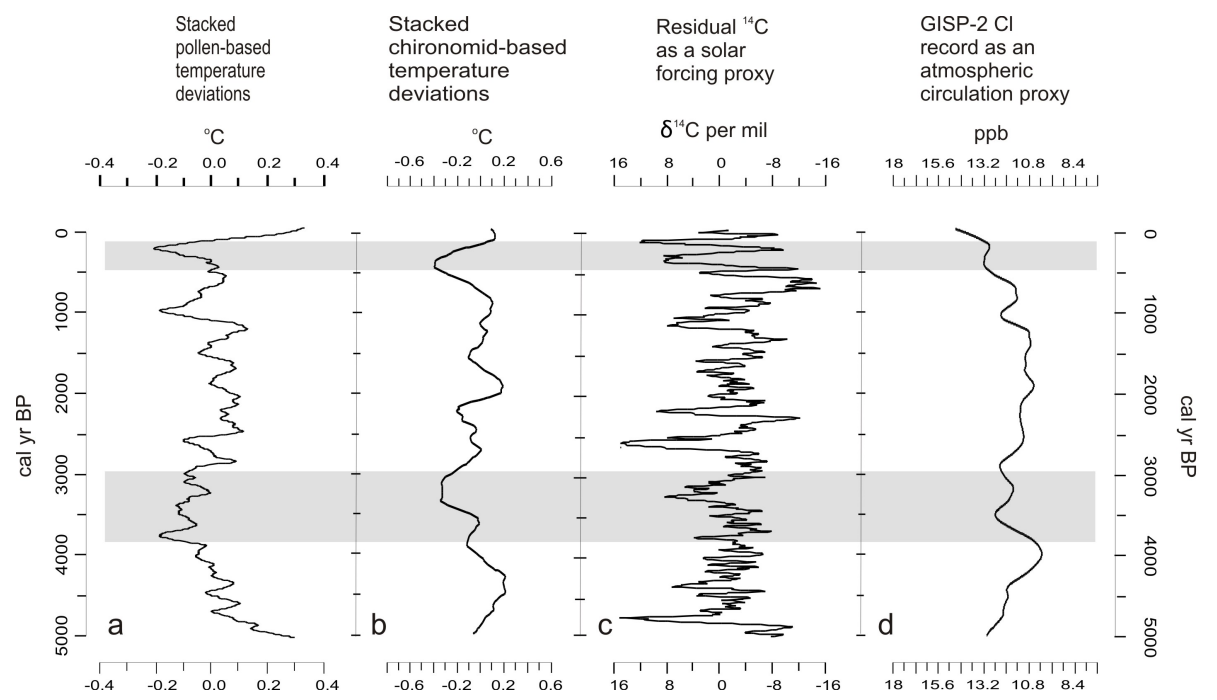

Fig. 5. Comparison of the reconstructed late-Holocene temperature variability with proxies that reflect possible forcings of the high-frequency variability. (a) the stacked summary pollen-based temperature variability record, as in Fig. 4a but with LOESS smoother with 0.03 . (b) the chironomid-based temperature variability record as in Fig. 4b, (c) the $\delta^{14} \mathrm{C}$ residuals as a proxy for solar radiation variability, unsmoothed, (d) the GISP-2 $\mathrm{Cl}$ ion concentration record as a proxy for the North Atlantic atmospheric circulation pattern variability (Mayewski et al., 1997). Smoothed with a LOESS smoother with span 0.1 .

values, as well as the dating errors in our summary records constructed from individual records dated with various dating techniques and accuracy.

\section{Conclusions}

We combined 36 pollen-based July mean and annual mean reconstructions from Northern Europe to investigate the temperature variability during the last 9000 years. The records range from the Norwegian Atlantic coast to $26^{\circ} \mathrm{E}$ in Estonia and Finland and from $57^{\circ} \mathrm{N}$ in Southern Fennoscandia to $70^{\circ} \mathrm{N}$ in the North. Most of the records centre on the temperate-boreal boundary in the south, the boreal-arctic boundary in Northern Fennoscandia or the boreal-alpine boundary in the Norwegian mountains. They are therefore sensitively located to capture temperature-driven changes in vegetation composition, vegetative growth patterns, and pollen productivity.

Our results show the well-established pattern of HTM, followed by a roughly linear cooling during the last 5000 years. The coolings at 8200 cal yr BP ("8.2 ka event") and at 500100 cal yr BP ("LIA") are the most significant abrupt events. The " $8.2 \mathrm{ka}$ event" is particularly clear in our stacked $T_{\text {ann }}$ record from the Baltic region, whereas the LIA occurs in the whole study region, particularly in the arctic and alpine regions with minimal human interference.

To examine more closely the temperature variability during the last 5000 years we compared our pollen-based detrended temperature record with a stacked chironomid-based July mean temperature record based on the data from seven sites from Fennoscandia. The general features of these two independent records support each other and suggest that, in addition to the cold anomaly during the LIA, another longer late-Holocene cold anomaly dates to $3800-3000$ cal yr BP. This anomaly is supported by some high-resolution records, but has not been widely reported earlier. These two cold anomalies are separated by a long warm spell peaking at 2000 cal yr BP, tentatively correlated here with the "Roman Warm Period" reported from Central Europe. The steady late-Holocene cooling trend has been reversed during the last 150 year. This post-LIA warming is consistent with the longterm meteorological and historical records from the region and represents the strongest warming trend since the warming at $8000 \mathrm{cal} \mathrm{yr} \mathrm{BP}$, after the $8.2 \mathrm{ka}$ event.

We suggest that the most direct driver of the late-Holocene anomalies has been changes in the dominant atmospheric circulation type. This seems likely in an area, where the modern temperature and precipitation values are highly variable depending on the changing circulation patterns. The anticyclonic circulation type, currently associated with the highest summer temperature, is a strong candidate as the mechanism behind the warm and dry late-Holocene anomalies. A more detailed analysis of the links between the reconstructed temperature patterns, inferred circulation changes, and the key late-Holocene forcing factors, such as the variability in ocean surface temperatures, solar irradiance, aerosols, greenhouse gas concentrations, and more complex combinations of these and other forcings, requires a more coherent analysis involving model experiments and will be a major palaeoclimatological task in the future. 
Acknowledgements. The authors acknowledge Dan Hammarlund, Ninis Rosqvist, Minna Väliranta and Gaute Velle for providing data and Marcela Tonello and two anonymous referees for constructive comments. Financial support for H. S. was provided by The Academy of Finland (HOT-project) and NordForsk (NEPALnetwork). This is a publication no. A236 from the Bjerknes Centre for Climate Research.

Edited by: H. Sundqvist

\section{References}

Alley, R. B. and Àgústsdóttir, A. M.: The 8k event: cause and consequences of a major Holocene abrupt climate change, Quaternary Sci. Rev., 10-11, 1123-1149, 2005.

Alley, R. B., Mayewski, P. A., Sowers, T., Stuiver, M., Taylor, K. C., and Clark, P. U.: Holocene climatic instability: A prominent, widespread event 8200 yr ago, Geology, 25, 483-486, 1997.

Almquist-Jacobson, H.: Lake-level fluctuations at Ljustjärnen, central Sweden and their implications for the Holocene climate of Scandinavia, Palaeogeogr. Palaeocl., 118, 269-290, 1995.

Andersson, G.: Hasseln i Sverige fordom och nu, Sveriges Geologiska Undersökning, Ser. C., 3, 1-168, 1902.

Andersson, G.: The climate of Sweden in the Late-Quaternary period, Sveriges geologiska undersökning, Ser. C., 3, 1-88, 1909.

Antonsson, K. and Seppä, H.: Holocene temperatures in Bohuslän, Southwestern Sweden: a quantitative reconstruction from fossil pollen data, Boreas, 36, 400-410, 2007.

Antonsson, K., Brooks, S. J., Seppä, H., Telford, R. J., and Birks, H. J. B.: Quantitative palaeotemperature records inferred from fossil chironomid and pollen assemblages from Lake Gilltjärnen, northern central Sweden, J. Quaternary Sci., 21, 831-841, 2006.

Antonsson, K., Chen, D., and Seppä, H.: Anticyclonic atmospheric circulation as an analogue for the warm and dry mid-Holocene summer climate in central Scandinavia, Clim. Past, 4, 215-224, 2008,

http://www.clim-past.net/4/215/2008/

Bakke, J., Lie, Ø., Dahl, S. O., Nesje, A., and Bjune, A. E.: Strength and spatial patterns of the Holocene wintertime westerlies in the NE Atlantic region, Global Planet. Change, 60, 28-41, 2008.

Beer, J. and van Geel, B.: Holocene climate change and the evidence for solar and other forcings, in: Natural climate variability and global warming: a Holocene perspective, edited by: Battarbee, R. W. and Binney, H. A., Wiley-Blackwell, Chichester, 138-162, 2008.

Berger, A. and Loutre, M.-F.: Insolation values for the climate of the last 10000000 years, Quaternary Sci. Rev., 10, 297-317, 1991.

Bergström, H. and Moberg, A.: Daily air temperature and pressure series from Uppsala (1722-1998), Climatic Change, 53, 213 252, 2002

Bigler, C., Larocque, I., Peglar, S. M., Birks, H. J. B., and Hall, R. I.: Quantitative multiproxy assessment of long-term patterns of Holocene environmental change from a small lake near Abisko, northern Sweden, Holocene 12, 481-496, 2002.

Birks, H. J. B.: Quantitative palaeoenvironmental reconstructions, in: Statistical modeling of quaternary science data, Technical Guide 5, edited by: Maddy, D. and Brew, J. S., Quaternary Research Association, Cambridge, 161-254, 1995.
Birks, H. J. B.: Numerical tools in quantitative palaeolimnology progress, potentialities, and problems, J. Paleolimnol., 20, 301332, 1998.

Birks, H. J. B.: Quantitative palaeoenvironmental reconstructions from Holocene biological data, in: Global Change in the Holocene, edited by: Mackay, A., Battarbee, R. W., Birks, H. J. B., and Oldfield, F., Arnold, London, 342-357. 2003

Bjune, A. E. and Birks, H. J. B.: Holocene vegetation dynamics and inferred climate changes at Svanåvatnet, Mo i Rana, northern Norway, Boreas, 37, 146-156, 2008.

Bjune, A. E., Birks, H. J. B., and Seppä, H.: Holocene vegetation and climate history on a continental - oceanic transect in northern Fennoscandia based on pollen and plant macrofossils, Boreas 33, 211-223, 2004.

Bjune, A. E., Seppä, H., and Birks, H. J. B.: Quantitative summertemperature reconstructions for the last 2000 years based on pollen-stratigraphical data from northern Fennoscandia, J. Paleolimnol., 41, 43-56, 2009.

Bond, G., Showers, W., Cheseby, M., Lotti, R., Almasi, P., deMenocal, P., Priore, P., Cullen, H., Hajdas, I., and Bonani, G.: A pervasive millennial-scale cycle in North Atlantic Holocene and glacial climates, Science, 278, 1257-1266, 1997.

Bond, G., Kromer, B., Beer, J., Muscheler, R., Evans, M. N., Showers, W., Hoffman, S., Lotti-Bond, R., Hajdas, I., and Bonani, G.: Persistent Solar Influence on North Atlantic Climate During the Holocene, Science, 294, 2130-2136, 2001.

Bonfils, C., de Noblet-Docoudré, N., Guiot, J., and Bartlein, P.: Some mechanims of mid-Holocene climate change in Europe, inferred from comparing PMIP models to data, Clim. Dynam., 23, 79-98, 2004.

Bradley, R. S. and Jones, P. D.: "Little Ice Age" summer temperature variations: their nature and relevance to recent global warming trend, Holocene, 3, 387-396, 1993.

Bradley, R. S., Hughes, M. K., and Diaz, H. F.: Climate in Medieval Time, Science, 302,404-405, 2003.

Busuioc, A., Chen, D., and Hellström, C.: Temporal and spatial variability of precipitation in Sweden and its link with the large scale atmospheric circulation, Tellus A, 53, 348-367, 2001.

Carrill, A. F., Gualdi, S. Cherchi, A., and Navarra, A.: Heatwaves in Europe: areas of homogeneous variability and links with the regional to large-scale atmospheric and SSTs anomalies, Clim. Dynam., 30, 77-98, 2008.

Charman, D. J., Brown, A. D., Hendon, D., and Karofeld, E. Testing the relationship between Holocene peatland palaeoclimate reconstructions and instrumental data at two European sites, Quaternary Sci. Rev., 23, 137-143, 2004.

Charman, D. J., Blundell, A., Chiverrell, R. C., Hendon, D., and Langdon, P. G.: Compilation of non-annually resolved Holocene proxy climate records: stacked Holocene peatland palaeo-water table reconstructions from northern Britain, Quaternary Sci. Rev., 25, 336-350, 2006.

Chen, D. and Hellström, C.: The influence of the North Atlantic Oscillation on the regional temperature variability in Sweden: spatial and temporal variations, Tellus A, 51(4), 505-516, 1999.

Crucifix, M., Loutre, M.-F., Tulkens, P., Fichefet, T., and Berger, A.: Climate evolution during the Holocene: a study with an Earth system model of intermediate complexity, Clim. Dynam., 19, 43-60, 2002.

Dahl, E.: The Phytogeoraphy of Northern Europe, Cambridge Uni- 
versity Press, Cambridge, 297 pp., 1998.

Dahl-Jensen, D., Monsegaard, K., Gundestrup, N., Clow, G. D., Johnsen, S. J., Hansen, A. W., and Balling, N.: Past Temperatures Directly from the Greenland Ice Sheet, Science, 282, 268-271, 1998.

Eide, W., Birks, H. H., Bigelow, N. H., Peglar, S. M., and Birks, H. J. B.: Holocene forest development along the Setesdal valley, southern Norway, reconstructed from macrofossil and pollen evidence, Veg. Hist. Archaeobot., 15, 65-85, 2006.

Giesecke, T., Bjune, A. E., Chiverrell, R. C., Seppä, H., Ojala, A. E. K., and Birks, H. J. B.: Exploring Holocene continentality changes in Fennoscandia using present and past tree distributions, Quaternary Sci. Rev., 27, 1296-1308, 2008.

Grosjean, M., Suter, P. J., Trachsel, M., and Wanner, H.: Ice-borne prehistoric finds in the Swiss Alps reflect Holocene glacier fluctuations, J. Quaternary Sci., 22, 203-207, 2007.

Grudd, H.: Torneträsk tree-ring width and density AD 500-2004: a test of climatic sensitivity and a new 1500-year reconstruction of north Fennoscandian summers, Clim. Dynam., 31, 843-857, 2008

Hammarlund, D., Björck, S., Buchardt, B., Israelson, C., and Thomsen, C. T.: Rapid hydrological changes during the Holocene revealed by stable isotope records of lacustrine carbonates from Lake Igelsjön, southern Sweden, Quaternary Sci. Rev., 22, $353-$ 370, 2003.

Heegaard, E.: CagedepthR.txt - R function for age-depth relationship estimation, available at: http://www.bio.uu.nl/ palaeo/ Congressen/Holivar/Literature_Holivar2003.htm, 2003.

Heegaard, E., Birks, H. J. B., and Telford, R. J.: Relationships between calibrated ages and depth in stratigraphical sequences: an estimation procedure by mixed-effect regression, Holocene, 15, 612-618, 2005.

Heikkilä, M. and Seppä, H.: A 11000 yr palaeotemperature reconstruction from the southern boreal zone in Finland, Quaternary Sci. Rev., 22, 541-554, 2003.

Heinrichs, M. L., Peglar, S. M., Bigler, C., and Birks, H. J. B.: A multi-proxy palaeoecological study of Alanen Laanijärvi, a boreal-forest lake in Swedish Lapland, Boreas, 34, 192-206, 2005.

Hicks, S.: The relationship between climate and annual pollen deposition at northern tree-lines, Chemosphere: Global Change Science 1, 403-416, 1999.

Hyvärinen, H. and Alhonen, P.: Holocene lake-level changes in the Fennoscandian tree-line region, western Finnish Lapland: diatom and cladoceran evidence, Holocene, 4, 251-258, 1994.

Jansen, E., Overpeck, J., Briffa, K. R., Duplessy, J.-C., Joos, F., Masson-Delmotte, V., Olago, D., Otto-Bliesner, B., Peltier, W. R., Rahmstorf, S., Ramesh, R., Raynaud, D., Rind, D., Solomina, O., Villalba, R., and Zhang, D.: Palaeoclimate, in: Climate Change 2007: The Physical Science Basis. Contribution of Working Group I to the Fourth Assessment Report of the Intergovernmental Panel on Climate Change, edited by: Solomon, S., Qin, D., Manning, M., Chen, Z., Marquis, M., Averyt, K. B., Tignor, M., and Miller, H. L., Cambridge University Press, Cambridge, United Kingdom and New York, NY, USA, 2007.

Jessen, C. A., Rundgren, M., Björck, S., and Hammarlund, D.: Abrupt climatic changes and an unstable transition into a late Holocene Thermal Decline: a multiproxy lacustrine record from southern Sweden, J. Quaternary Sci., 20, 349-362, 2005.
Jones, P. D. and Lister, D. H.: The influence of the circulation on surface temperature and precipitation patterns over Europe, Clim. Past, 5, 259-267, 2009, http://www.clim-past.net/5/259/2009/.

Jongma, J. Prange, M., Renssen, H., and Schulz, M.: Amplification of Holocene multicentennial climate forcing by mode transitions in North Atlantic overturning circulation, Geophys. Res. Lett., 34, LI5706, doi:10.1029/2007/GL030642, 2007.

Jörin, U. E., Stocker, T. F., and Schlüchter, C.: Multicentury glacier fluctuations in the Swiss Alps during the Holocene, Holocene 16, 697-704, 2006.

Kaufman, D. S., Ager, T. A., Anderson, N. J., Anderson, P. M., Andrews, J. T., Bartlein, P. T., Brubaker, L. B., Coats, L. L., Cwynar, L. C., Duvall, M. L., Dyke, A. S., Edwards, M. E., Eisner, W. R., Gajewski, K., Geirsdottir, A., Hu, F. S., Jennings, A. E., Kaplan, M. R., Kerwin, M. W., Lozhkin, A. V., MacDonald, G. M., Miller, G. H., Mock, C. J., Oswald, W. W., Otto-Bliesner, B. L., Porinchu, D. F., Ruhland, K., Smol, J. P., Steig, E. J., and Wolfe, B. B.: Holocene thermal maximum in the western Arctic (0-180 W), Quaternary Sci. Rev., 23, 529-560, 2004.

Kaufman, D. S., Schneider, D. P., McKay, N. P., Ammann, C. M., Bradley, R. S., Briffa, K. R., Miller, G. H., Otto-Bliesner, P. L., Overpeck, J. T., and Arctic Lakes 2k Project Members: Recent Warming Reverses Long-Term Arctic Cooling, Science, 325, 1236-1239, 2009.

Korhola, A., Tikkanen, M., and Weckström, J.: Quantification of Holocene lake-level changes in Finnish Lapland using a cladocera-lake depth transfer function, J. Paleolimnol., 34, 175190, 2005.

Lamb, H. H.: Climate, History and the Modern World. Methuen, London, 387 pp., 1982.

Larsen, L. B., Vinther, B. M., Briffa, K. R., Melvin, T. M., Clausen, H. B., Jones, P. D., Siggaard-Andersen, M. L., Hammer, C. U., Eronen, M., Grudd, H., Gunnarsson, B. E., Hantemirov, R. M., Naurzbaev, M. M., and Nicolussi, K.: New ice core evidence for a volcanic cause of the A.D. 536 dust veil, Geophys. Res. Lett., 35, L04708, doi:10.1029/2007GL032450, 2008.

Lotter, A. F., Birks, H. J. B., Eicher, U., Hofmann, W., Schwander, J., and Wick, L.: Younger Dryas and Allerød summer temperatures at Gerzensee (Switzerland) inferred from fossil pollen and cladoceran assemblages, Palaeogeogr. Palaeocl., 159, 349-361, 2000.

Magny, M. and Haas, J.-N.: A major widespread climatic change around $5300 \mathrm{cal}$. yr BP at the time of the Alpine Iceman, J. Quaternary Sci., 19, 423-430, 2004.

Mann, M. E.: Climate Over the Past Two Millennia, Annu. Rev. Earth Pl. Sc., 35(1), 111-136, 2007.

Mayewski, P. A., Meeker, L. D., Twickler, M. S., Whitlow, S., Yang, Q., Lyons, W. B., and Prentice, M.: Major features and forcing of high-latitude northern hemisphere atmospheric circulation using a 110000 -year long glaciochemical series, J. Geophys. Res.Oceans, 102, 26345-26366, 1997.

Moberg, A., Sonechkin, D., Holmgren, K., Datsenko, N. M., and Karlén, W.: Highly variable Northern Hemisphere temperatures reconstructed from low- and high-resolution proxy data, Nature, 433, 613-617, 2005.

Moros, M., Emeis, K., Risebrobakken, B., Snowball, I., Kuijpers, A., McManus, J., and Jansen, E.: Sea surface temperatures and ice rafting in the Holocene North Atlantic: climate influences 
on Northern Europe and Greenland, Quaternary Sci. Rev., 23, 2113-2126, 2004.

Nesje, A., Matthews, J. A., Dahl, S. O., Berrisford, M. S., and Andersson, C.: Holocene glacier fluctuations of Flatebreen and winter-precipitation changes in the Jostedalsbreen region, Holocene, 11, 267-280, 2001.

O'Brien, S. R., Mayewski, P. A, Meeker, L. D., Meese, D. A., Twickler, M. S. and Whitlow, S. I.: Complexity of Holocene climate as reconstructed from a Greenland ice core, Science 270, 1962-1964, 1995.

Ojala, A. E. K. and Tiljander, M.: Testing the fidelity of sediment chronology: comparison of varve and paleomagnetic results from Holocene lake sediments from central Finland, Quaternary Sci. Rev., 22, 1787-1803, 2003.

Ojala, A. E. K., Alenius, T., Seppä, H., and Giesecke, T.: Integrated varve and pollen-based temperature reconstruction from Finland: evidence for Holocene seasonal temperature patterns at high latitudes, Holocene, 18, 529-538, 2008.

Oppo, D. W., McManus J. F., and Cullen, J. L.: Deepwater variability in the Holocene epoch, Nature, 422, 277-278, 2003.

Philipp, A., Della-Marta, P. M., Jacobeit, J., Fereday, D. R., Jones, P. D., Moberg, A., and Wanner, H.: Long-term variability of daily North Atlantic-European pressure patterns since 1850 classified by simulated annealing clustering, J. Climate, 20, 4065-4095, 2007.

Prentice, I. C., Harrison, S. P., Jolly, D., and Guiot, J.: The climate and biomes of Europe at $6000 \mathrm{yr}$ BP: Comparison of model simulations and pollen-based reconstructions, Quaternary. Sci. Rev., 17, 659-668, 1998.

Reimer, P. J., Baillie, M. G. L., Bard, E., Bayliss, A., Beck, J. W., Bertrand, C. J. H., Blackwell, P. G., Buck, C. E., Burr, G. S., Cutler, K. B., Damon, P. E., Edwards, R. L., Fairbanks, R. G., Friedrich, M., Guilderson, T. P., Hogg, A. G., Hughen, K. A., Kromer, B., McCormac, G., Manning, S., Bronk Ramsey, C., Reimer, R. W., Remmele, S., Southon, J. R., Stuiver, M., Talamo, S., Taylor, F. W., van der Plicht, J., and Weyhenmeyer, C.E.: INTCAL04 terrestrial radiocarbon age calibration, 0-26 cal KYR BP, Radiocarbon, 46, 1029-1058, 2004.

Renssen, H., Goosse, H., Fichefet, T., Brovkin, V., Driesschaert, E., and Wolk, F.: Simulating the Holocene climate evolution at northern high latitudes using a coupled atmosphere-sea iceocean-vegetation model, Clim. Dynam., 24, 23-43, 2005.

Renssen, H., Goosse, H., and Muscheler, R.: Coupled climate model simulation of Holocene cooling events: oceanic feedback amplifies solar forcing, Clim. Past, 2, 79-90, 2006, http://www.clim-past.net/2/79/2006/.

Renssen, H., Seppä, H., Heiri, O., Fichefet, T., Goosse, H., and Roche, D. M.: The spatial and temporal complexity of the Holocene thermal maximum, Nature Geoscience, 2, 411-414, 2009.

Rimbu, N., Lohmann, G., Lorenz, S. J., Kim, J. H., and Schneider, R. R.: Holocene climate variability as derived from alkenone sea surface temperature and coupled ocean-atmosphere model experiments, Clim. Dynam., 23, 215-227, 2004.

Risebrobakken, B., Jansen, E., Andersson, C., Mjelde E., and Hevrøy, K.: A high-resolution study of Holocene paleoclimatic and paleoceanographic changes in the Nordic Seas, Paleoceanography, 18, 1-14, 2003.

Rosén, P., Segerström, U., Eriksson, L., Renberg, I., and Birks, H.
J. B.: Holocene climatic changes reconstructed from diatoms, chironomids, pollen and near-infrared spectroscopy at an alpine lake (Sjuodjijaure) in northern Sweden, Holocene, 11, 551-567, 2002.

Rosqvist, G. C., Leng, M. J., and Jonsson, C.: North Atlantic region atmospheric circulation dynamics inferred from a late-Holocene lacustrine carbonate isotope record, northern Swedish Lapland, The Holocene, 17, 867-873, 2007.

Rundgren, M.: Stratigraphy of peatlands in central and northern Sweden: evidence of Holocene climate change and peat accumulation, GFF, 130, 95-107, 2008.

Sarmaja-Korjonen, K. and Seppä, H.: Abrupt and consistent responses of aquatic and terrestrial ecosystems to the 8200 cal. yr BP cold event: a lacustrine record from Lake Arapisto, Finland, Holocene, 17, 455-464, 2007.

Schulz, M., Paul, A., and Timmermann, A.: Glacialinterglacial contrast in climate variablity at centennial-tomillennial timescales: observations and conceptual model, Quaternary Sci. Rev., 23, 2219-2230, 2004.

Seppä, H.: Postglacial trends in palynological richness in the northern Fennoscandian tree-line area and their ecological interpretation, Holocene, 8, 43-53, 1998.

Seppä, H. and Birks, H. J. B.: July mean temperature and annual precipitation trends during the Holocene in the Fennoscandian tree-line area: pollen based reconstructions, Holocene, 11, 527539, 2001.

Seppä, H. and Birks, H. J. B.: Holocene climate reconstructions from the Fennoscandian tree-line area based on pollen data from Toskaljavri, Quaternary Res., 57, 191-199, 2002.

Seppä, H., Nyman, M., Korhola, A., and Weckström, J.: Changes of tree-lines and alpine vegetation in relation to post-glacial climate dynamics in northern Fennoscandia based on pollen and chironomid records, J. Quaternary Sci., 17, 287-301, 2002.

Seppä, H. and Poska, A.: Holocene annual mean temperature changes in Estonia and their relationship to solar insolation and atmospheric circulation patterns, Quaternary Res., 61, 22-31, 2004.

Seppä, H., Birks, H. J. B., Odland, A., Poska, A., and Veski, S.: A modern pollen-climate calibration set from Northern Europe: testing and developing a tool for palaeoclimatological reconstructions, J. Biogeogr., 31, 251-267, 2004.

Seppä, H., Hammarlund, D., and Antonsson, K.: Low-frequency and high-frequency changes in temperature and effective humidity during the Holocene in south-central Sweden: implications for atmospheric and oceanic forcings of climate, Clim. Dynam., 25, 285-297, 2005.

Seppä, H., Birks, H. J. B., Giesecke, T., Hammarlund, D., Alenius, T., Antonsson, K., Bjune, A. E., Heikkilä, M., MacDonald, G. M., Ojala, A. E. K., Telford, R. J., and Veski, S.: Spatial structure of the $8200 \mathrm{cal}$ yr BP event in Northern Europe, Clim. Past, 3, 225-236, 2007, http://www.clim-past.net/3/225/2007/.

Seppä, H., MacDonald, G. M., Birks, H. J. B, Gervais, B. R., and Snyder, J. A.: Late-Quaternary summer temperature changes in the North-European tree-line region, Quaternary Res., 69, 404412, 2008.

Sohar, K. and Kalm, V.: A 12.8-ka-long palaeoenvironmental record revealed by subfossil ostracod data from lacustrine freshwater tufa in Lake Sinijärv, northern Estonia, J. Paleolimnol., 40, 
809-821, 2008.

Sommer, R. S., Lindqvist, C., Persson, A., Bringsøe, H., Rhodin, A. G., Schneeweiss, N., Široký, P., Bachmann, L., and Fritz, U.: Unexpected early extinction of the European pond turtle (Emys orbicularis) in Sweden and climatic impacts on its Holocene range, Mol. Ecol., 18, 1252-1262, 2009.

Steig, E.: Mid-Holocene Climate Change, Science, 286, 148-149, 1999.

Stuiver, M. and Reimer, P.: Extended ${ }^{14} \mathrm{C}$ data base and revised CALIB 3.0 ${ }^{14} \mathrm{C}$ age calibration program, Radiocarbon, 35, 215230, 1993.

Stuiver, M., Reimer, P. J., and Reimer, R. W.: CALIB 5.0 (www program and documentation), 2005.

Stuiver, M., Reimer, P. J., Bard, E., Burr, G. S., Hughen, K.A, Kromer, B., McCormac, G., van der Plicht, J., and Spurk, M.: INTCAL98 Radiocarbon Age Calibration, Radiocarbon, 40, 1041-1083, 1998.

Tarand, A. and Nordli, P.Ø.: The Tallinn temperature series reconstructed back half a millennium by use of proxy data, Climatic Change, 48, 189-199, 2001.

TEMPO-members, Kutzbach, J. E., Bartlein, P. J., Foley, J. A., Harrison, S. P., Hostetler, S. W., Liu, Z., Prentice, I. C., and Webb III, T.: Potential role of vegetation feedback in the climate sensitivity of high-latitude regions: a case study at 6000 years before present, Global Biogeochem. Cy., 10, 727-736, 1996.

ter Braak, C. J. F. and Juggins, S.: Weighted averaging partial least squares regression (WA-PLS): an improved method for reconstructing environmental variables from species assemblages, Hydrobiologia, 269/270, 485-502, 1993.

ter Braak, C. J. F., Juggins, S., Birks, H. J. B., and van der Voet, H.: Weighted averaging partial least squares regression (WAPLS): definition and comparison with other methods for speciesenvironmental calibration, in: Multivariate environmental statistics, edited by: Patil, G. P. and Rao, C. R., Elsevier, Amsterdam, 525-560, 1993.

Turney, C., Baillie, M., Clemens, S., Brown, D., Palmer, J., Pilcher, J., Reimer, P., and Leuschner, H. H.: Testing solar forcing of pervasive Holocene climate cycles, J. Quaternary Sci., 20, 511$518,2005$.
Väliranta, M., Korhola, A., Seppä, H., Sarmaja-Korjonen, K., Tuittila, E.-S., Laine, J., and Alm, J.: High-resolution reconstruction of wetness dynamics in a southern boreal raised bog, Finland, during the late Holocene: a quantitative approach, Holocene, 17 , 1093-1107, 2007.

Velle, G., Brooks, S. J., Birks, H. J. B., and Willassen, E.: Chironomids as a tool for inferring Holocene climate: an assessment based on six sites in southern Scandinavia, Quaternary Sci. Rev., 24, 1429-1462, 2005.

Veski, S., Seppä, H., and Ojala, A. E. K.: Cold event at 8200 yr B.P. recorded in annually laminated lake sediments in eastern Europe, Geology, 32, 681-684, 2004.

Vollweiler, N., Scholz, D., Mühlinghaus, C., Mangini, A., and Spötl, Ch.: A precisely dated climate record for the last $9 \mathrm{kyr}$ from three high alpine stalagmites, Spannagel Cave, Austria, Geophys. Res. Lett., 33, L20703, doi:10.1029/2006GL027662, 2006.

Walther, A. and Linderholm, H. W.: A comparison of growing season indices for the Greater Baltic Area, Int. J. Biometeorol., 51, 107-118, 2006.

Wanner, H., Beer, J., Butikofer, J., Crowley, T. J., Cubasch, U., Fluckiger, J., Goosse, H., Grosjean, M., Joos, F., Kaplan, J. O., Kuttel, M., Muller, S. A., Prentice, I. C., Solomina, O., Stocker, T. F., Tarasov, P., Wagner, M., and Widmann, M.: Mid-to Late Holocene climate change: an overview, Quaternary Sci. Rev., 27, 1791-1828, 2008.

Weber, S. L., Crowley, T. J., and van der Schrier, G.: Solar irradiance forcing of centennial climate variability during the Holocene, Clim. Dynam., 22, 539-553, 2004.

Weckström, J., Korhola, A., Erästo, P., and Holmström, L.: Temperature patterns over the eight past centuries in Northern Fennoscandia inferred from sedimentary diatoms, Quaternary Res., 66, 78-86, 2006.

Wiersma, A. P. and Renssen, H.: Model-data comparison for the $8.2 \mathrm{ka}$ BP event: Confirmation of a forcing mechanism by catastrophic drainage of Laurentide Lakes, Quaternary Sci. Rev., 25, 63-88, 2006 